\title{
Collaborative Governance and its Role in Fighting the Pandemic: From the Conception of What it is to the Verification of its Inexistence
}

By Valdir Roque Dallabrida, Daniel Knebel Baggio, Alexandre Zatera \& Princela Santana Da Cruz

Abstract-Complex problems such as the public management of a pandemic require coordinated and horizontal action, involving not only public officials and their state agents but also representatives of civil society, their universities, and researchers, the technical and the corporate staff in the health field, such as collaborative governance practices. However, what we observed in Brazil in the Covid-19 first months of the pandemic, was the intensified action in the government sphere, with precarious effectiveness and little coordinative efficiency.

Keywords: public management. collaborative governance. territorial governance. covid-19 pandemic.

GJHSS-H Classification: FOR Code: 940299

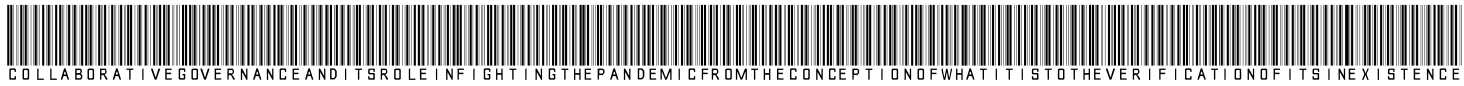

Strictly as per the compliance and regulations of:

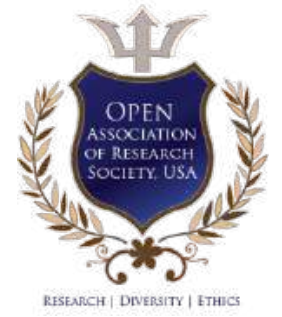

(C) 2020. Valdir Roque Dallabrida, Daniel Knebel Baggio, Alexandre Zatera \& Princela Santana Da Cruz. This is a research/review paper, distributed under the terms of the Creative Commons Attribution-Noncommercial 3.0 Unported License http://creative commons.org/licenses/by-nc/3.0/), permitting all non-commercial use, distribution, and reproduction in any medium, provided the original work is properly cited. 


\title{
Collaborative Governance and its Role in Fighting the Pandemic: From the Conception of What it is to the Verification of its Inexistence
}

\author{
Governança Colaborativa E Seu Papel No Combate À Pandemia Covid-19: Da \\ Concepção Sobre O Que Se Trata À Constatação Da Sua Inexistência
}

\section{Gobernanza Colaborativa Y Su Papel En La Lucha Contra La Pandemia Covid-19: Desde La Concepción De Lo Que Es Hasta La Comprensión De Su Inexistencia}

\author{
Valdir Roque Dallabrida ${ }^{\alpha}$, Daniel Knebel Baggio ${ }^{\circ}$, Alexandre Zatera ${ }^{\circ} \&$ Princela Santana Da Cruz ${ }^{\omega}$
}

Abstract- Complex problems such as the public management of a pandemic require coordinated and horizontal action, involving not only public officials and their state agents but also representatives of civil society, their universities, and researchers, the technical and the corporate staff in the health field, such as collaborative governance practices. However, what we observed in Brazil in the Covid-19 first months of the pandemic, was the intensified action in the government sphere, with precarious effectiveness and little coordinative efficiency.

Keywords: public management. collaborative governance. territorial governance. covid-19 pandemic.

Resumo- Problemas complexos, como a gestão pública de uma pandemia exige a ação coordenada e horizontal, envolvendo não apenas dirigentes públicos com seus agentes estatais, mas representações da sociedade civil, suas universidades e pesquisadores, além de quadros técnicos e empresariais da ár ea da saúde, como práticas de governança colaborativa. No entanto, o que se observou no Brasil nesses primeiros meses de presença da pandemia Covid-19 foram ações concentradas na esfera governamental, com precária eficácia e pouca eficiência coordenativa.

Palavras-Chave: gestão pública. governança colaborativa. governança territorial. pandemia covid-19.

Resumen- Los problemas complejos, como la gestión pública de una pandemia, requieren una acción coordinada y horizontal, que involucre no solo a los funcionarios públicos con sus agentes estatales, sino también a las

Author a: Geógrafo, Doutor em Desenvolvimento Regional. Programa de Pós-graduação em Desenvolvimento Regional (Mestrado e Doutorado). Universidade do Contestado (UnC), SC, Brasil.

e-mail: valdirdallabrda@gmail.com

Author o: Administrador, Mestre e Doutor em Contabilidade e Finanças. Programa de Pós-graduação em Desenvolvimento Regional (Mestrado e Doutorado), Programa de Pós-graduação em Gestão de Estratégica de Organizações (Mestrado Profissional). Universidade Regional do Noroeste do Estado do Rio Grande do Sul (UNIJUI) e Universidade Regional Integrada da Missões e do Alto Uruguai (URI), RS, Brasil. e-mail: danibaggio@gmail.com

Author $\rho$ w: Psiquiatra, Mestrando em Desenvolvimento Regional. Programa de Pós-graduação em Desenvolvimento Regional (Mestrado e Doutorado). Universidade do Contestado (NnC), SC, Brasil.e-mails: a.zatera@gmail.com, princela@unc.br representaciones de la sociedad civil, sus universidades e investigadores, además del personal técnico y comercial en el campo de la salud, como prácticas de gobierno colaborativo. Sin embargo, lo que se observó en Brasil en los primeros meses de la pandemia de Covid-19 fueron acciones concentradas en la esfera gubernamental, con efectividad precaria y poca eficiencia de coordinación.

Palabras clave: gestión pública. gobernanza colaborativa. gobernanza territorial. covid-19 pandemia.

\section{INTRODUCTION}

$\longrightarrow$ overnance is a term present in different areas of knowledge, even though with slightly different meanings. According to Coase (1937), firstly and later to Williamson (1996), it refers to the devices used by the company to achieve effective coordination to reduce transaction costs, contributing therefore to economic growth. The theoretical basis for the discussion on governance is based on institutionalist economists and follows a corporate point of view.

In 1975, the governability of democracies was the object of analysis and its central hypothesis was that such governability problems in Western Europe, Japan and in the United States happened due to the gap between the increase in social demands and the lack of both financial and human resources, not to mention the inability of public management (Milani \& Solinís, 2002). With the pass of time, the term started to describe arrangements of socio-political nature.

The formation of such collaborative arrangements would be justified by the recognition that each of the organizations involved, whether public or private, do not have the necessary skills to respond individually to the needs of consumers and citizens who make up contemporary society (Sørensen \& Torfing, 2007). Despite demands for new ways of government in a global socio-economic-political context, whereby new governance ways are emerging, according to Jessop 
(2006), it is essential to keep the National State playing the central political role; its duty may not be reduced but redefined by contemporary changes.

Mayntz (1998) prefers to call it governance, a more cooperative way of governing, different from the old hierarchical model in which the state authorities exercised sovereign power over groups and citizens in a civil society. In this new format, state and non-state institutions, public and private actors participate and often cooperate in the formulation and implementation of public policies.

Kooiman (2004) refers to governance as a pattern or structure that emerged from the socio-political system, looking for shared purposes in the group of actors. They interact in each environment, implying, therefore, the presence of a polycentric state.

Consequently, limits would be set for a central actor to govern, and there would no longer be a single sovereign authority. These socio-political-administrative actors would share goals, with imprecise boundaries between public, private, and voluntary sectors, multiplying the forms of intervention, action, and control. It is about structuring governance practices of high complexity into management processes, issues, and problems that are also intricate, specifically, governance practices. This text intends to deliberate over this theme.

The governance processes take place historically and territorially, so one can speak of territorial governance. Next, we shall delve on theoretical contributions for a broad understanding of collaborative governance, its stages, and characterization. These first two parts of the text consist of the literature review about the subject, while the third part presents an integrative synthesis between territorial and collaborative governance. This concept contextualizes the case of public management related to the Covid-19 pandemic. The fourth part refers to management actions related to the Covid-19 in Brazil; the analysis and the conclusion that, unfortunately, there are no collaborative governance practices being implemented, as presented in this theoretical basis. To substantiate the studies, it was necessary to consult official websites, and to check facts and initiatives of the public authorities, being our reference what the press had disclosed on the subject.

\section{il. Territorial Governance}

Synthetically, the concept of governance refers to the collaborative arrangements formed to manage public actions, involving state agents, the civil society, and the corporate sector. We structured the meaning of territorial governance by understanding that the effectiveness of its processes occurs two ways: historically and territorially.

The conceptual category of territorial governance, despite its recent use, is already transcribed in three different Brazilian dictionaries of
Portuguese (Dallabrida, 2006, 2014, 2017). The introduction of the concept in literature starts from the understanding that it is within the territory (as a way of living) that men shall express different forms of action and power. They are manifested in cooperative relations, but also in conflict, where there is the concreteness of people's different ways of thinking and acting. Thus, territorial management processes are complex, requiring the coordinated and collaborative action of state agents, civil society representatives, and market players through governance practices.

Territorial governance is the process of planning and managing dynamics, by prioritizing and innovating, shared, and collaborative approach through horizontal relations. However, this process includes power struggles, discussions, negotiations, and deliberations among state agents, representatives of the social and business sectors, research centers, and higher education institutions. Processes of this nature are based on an irreplaceable role of the State, a good notion of democracy, and on the part of civil society, aiming to harmonize a vision about the future and a pattern of territorial development (Dallabrida, 2015a, p. 325) ${ }^{1}$.

Therefore, territorial governance practices are intrinsically related to the development process of regions and territories. According to Farinós (2008), territorial governance ultimate purpose is sustainable development, while its objective is social cohesion. Efficient territorial governance is a relevant precondition for strengthening national cohesion. It is a practice/ process of organizing multiple relationships that characterize interactions among different actors and interests in a territory, to develop a shared territorial vision sustained by the identification and appraisal of the territorial heritage ${ }^{2}$.

There are different options, conditions, and limitations for the practice of territorial governance. In this sense, Farinós (2015) defends the need and convenience to expand the prevailing governanceeconomy relations, with a new and more powerful relationship between politics and territory. According to the author, the aim is to improve governability from the perspective of a more decent territorial development, a better democracy, and the population's well-being.

Therefore, we realize territorial governance processes turn public-private consultation practices effective (Dallabrida, 2003)once it defines future perspectives of people who live in the territory going beyond economics and including health, leisure, and the people's quality of life.

\footnotetext{
1 To check more about this subject in other publications: Dallabrida (2015b; 2018).

${ }^{2}$ About territorial heritage and its relation to Territorial Governance, see Dallabrida (under publication).
} 


\section{ili. Collaborative Governance}

Collaborative governance is a standard oriented to achieve consent and to cooperatively produce results and solutions, as a contemporary perspective of interest management and as a mechanism of solving complex problems (Ansel \& Gash, 2007; Bodin, 2017), in especially those related to the public sphere (Emerson, Nabatchi \& Balogh, 2012). The challenge of conducting a collaborative governance model implies mainly in balancing the different interests of the actors involved in the management process. It is different from other ways of governing and from other decision-making processes that require consensus since collaborative governance goal is to solve complex issues and problems (Bodin,
2017). In other words, governance practices are interdependent among actors, even they shall remain functionally independent from state institutions, from companies, non-profit organizations, and representatives of civil society (Taylor, De Loë \& Bjornlund, 2012). Finally, collaborative governance models or collaborative virtual communities demonstrate the potential for driving value co-creation and co-innovation (Romero \& Molina, 2011).

As you can see in Table 1. Ansell and Gash (2007) propose a model of Collaborative Governance based on the ever-growing trust among actors and the consolidation of a more cooperative behavior based on dialogue.

\section{Table 1: Development Stages of Collaborative Governance}

\begin{tabular}{|l|l|}
\hline \multicolumn{1}{|c|}{ Stages } & \multicolumn{1}{c|}{ Stage Description } \\
\hline $\begin{array}{l}\text { Face to face } \\
\text { communication }\end{array}$ & $\begin{array}{l}\text { Each and every collaborative governance is based on face-to-face dialogue between } \\
\text { stakeholders. As a consensus-driven process, the "direct communication" enabled by } \\
\text { direct dialogue is necessary for stakeholders to identify opportunities for mutual gain. }\end{array}$ \\
\hline Building Trust & $\begin{array}{l}\text { Collaborative processes are not only about negotiation, but also about building trust } \\
\text { among stakeholders. }\end{array}$ \\
\hline $\begin{array}{l}\text { Commitment } \\
\text { with the } \\
\text { process }\end{array}$ & $\begin{array}{l}\text { The design of the decision-making process in collaborative governance mechanisms is } \\
\text { crucial to trust building, once it prevents favoritism and clientelism. }\end{array}$ \\
\hline $\begin{array}{l}\text { Shared vision } \\
\text { of the future }\end{array}$ & $\begin{array}{l}\text { At some point through the collaborative process, stakeholders must develop a shared } \\
\text { understanding of what they can achieve together. }\end{array}$ \\
\hline
\end{tabular}

Source: Adapted from Anseel and Gash (2007)

From the presented framework, it is possible to observe the consolidation of collaborative governance among actors involved in the shared decision-making process in the territory.

Based on a bibliometric study of publications on collaborative governance published in the Web of Science database from 2009 to 2018, the studies by Anseel and Gash (2007), Bartz, Turcato and Baggio (2019) acknowledge collaborative governance as a stable arrangement made up of actors who have complementary resources and therefore depend on one another for the achievement of converging goals.

\section{An Integrative Synthesis between Territorial and Collaborative Governance}

In summary, the focus on territorial governance and collaborative governance derive both from the general concept of the word, as a way of governing that is different from the old hierarchical model concentrated on the state (Mayntz, 1998); a sociopolitical system is acting in search of alike purposes on behalf of the actors who interact in a determined environment (Kooiman, 2004). Therefore, they are not exclusive.

The focus on territorial governance lies in the understanding that public policies, in general, aim at the territory as a means of life for the people, as space where things happen. Therefore, any governance practice aiming to reach local social groups is territorial and inevitably, horizontal, and collaborative. On the other hand, the focus on collaborative governance emphasizes the extent of collaboration, or sharing, in the decision-making process. Such a dimension is not entirely disregarded by a territorial approach once it strengthens interorganizational relationships and balances different interests of the actors involved (Bodin, 2017).

In any case, the word of Ferrão (2013) on governance processes (territorial and collaborative) is valuable: the more fragile political institutions and civil society are, the bigger are the chances of forms of governance to become arenas of a decision taken by organized interests. Without accountability and democratic control, many types of governments can effortlessly become instruments of inequality and injustice in favor of crony interests or populist behavior. For this reason, the debate on forms of governance integrates with the one on the types of democratic control.

What is unique about both approaches to the theme is that they are ways of solving complex problems (Ansel \& Gash, 2007; Bodin, 2017), especially those related to the public sphere (Emerson et al., 2012). 
A current example of an intricate issue related to the public sphere is the process of managing solutions to the Covid-19 pandemic, which is not a matter of management measures, but governmental. It implies collaborative and horizontal involvement of health representatives - especially on infectious diseases along with government action. In this case, collaborative governance practices require the involvement of government officials and technicians of interdisciplinary teams, with representation from academia, civil society, and the corporate health sector.

Afterward, we intend to analyze the efforts from the Brazilian government in the management of actions regarding the Covid-19 pandemic, covering the period of February to April 2020.

\section{Management Actions Related to the Pandemic Covid-19 in Brazil}

The socio-political moment experienced in the world, and particularly in Brazil, presents certain unfavorable factors to solve complex and unexpected situation as a world pandemic. Such factors include the globalization process consolidation; man's belief in his supremacy over nature; the estrangement in historical political relations; the preeminence of the elite in the world in articulation with liberal political positions of their rulers; little appreciation of cooperation, humanism, trust, solidarity among people and institutions. Among possible consequences, intense processes of corrosion of democracy.

The liberal position of the rulers, reducing investments in health, education, and social assistance shapes the background of the pandemic Brazil. In this scenario of lack of democratic practices and of social/welfare crisis that the Covid-19 pandemic emerges, demanding urgent measures from the government and the society. Even though several initiatives came up, what is observed is that the power of decision has not gone beyond the sphere of government.

The main legal instrument related to the management of the pandemic was the Federal Government Decree No. 10,277 (2020a), which established the Comitê de Crise para Supervisão e Monitoramento dos Impactos da Covid-19, the literal translation for "Crisis Committee for Supervision and Monitoring of Covid-19 Impacts". The composition of the Committee includes the Ministry of Health, plus fourteen Ministers of the Federal Government, members of the Attorneys General Office, Anvisa (National Sanitary Surveillance), the Central Bank, Banco do Brasil and Caixa Econômica Federal (both federal banks), The National Bank of Economic and Social Development (BNDS) and the Center of Operations of Emergencies in Public Health of the Secretariat of Surveillance.
Also, the Decree 10,289 (2020b) establishes the Centro de Coordenação de Operações (Operations Coordination Center), within the Covid-19 Committee, to coordinate federal government's operations, articulating actions with public and private entities to confront Covid-19 and its impacts, and monitoring actions taken by public and private actors. The Operations Center also includes other federal agencies, such as the Institutional Security Office, National Agencies such as Anvisa, Anac (bureau responsible for aviation in Brazil), Anatel (responsible for telecommunications), Antt (bureau in charge of transportation), the Brazilian Intelligence Agency, the Civil Defense, the Federal Police, and the Highway Police.

Both decrees provide for the exclusive participation of government agents and representatives of different state agencies, therefore excluding representatives of the civil society and from the corporate sector, and even other institutions such as universities and medical researchers. In the sphere of the Brazilian Federal Government, the structures legally foreseen are not characterized as structures of collaborative governance.

Within the governmental realm of Brazilian States and Municipalities, the situation is the same, with few exceptions. Different management structures have been formed statewide. From what has been possible to access by the press, websites, and from available documents, the example of the Brazilian state of Ceará is what comes closest to a so-called structure of collaborative governance, despite the absence of civil society. Such chain of events led to the structuring of the Committee for Confronting the Coronavirus Pandemic, formed by representations of twenty-five entities or boards, such as the state secretariats, Fortaleza City Hall, Legislative Assembly, State, and Federal Prosecutors, Court of Auditors, Ministry of Labor, Bar Association, Federal Justice, District Attorney's Office, Association of Municipalities, Cearense Association of Radio and TV Broadcasters, Council of Store Directors (CDL), State and Federal Universities of Ceará, federations of industry and commerce and the Penitentiary Administration. There is the representation of the legislature, the business sector, and local universities despite the predominance of state agents. Other states have structured different types of management committees formed mainly by state agents. Meetings of the Steering Committee with the corporate and with the medical-hospital sector have occurred, though.

We observed the very same situation in the municipalities. To name two examples, in the town of Osvaldo Cruz (SP), a Crisis and Emergency Management Committee was set up, with the participation of the president of the Commercial and Business Association, the Retail Trade Union and the 
Economic and Social Development Forum, plus members of the municipal government structure. Again, representations from civil society or university institutions remain absent. In the Municipality of Irani (SC), the Crisis Management Committee was set up by municipal government agents, representatives of epidemiological surveillance, the Municipal Health Council, the municipal medical staff, the City Council, and the Retailers Association. Other cases include, in addition to state agents, members of the health sector, and representatives of the local hospital entity.

\section{Vi. Final Considerations}

Finally, we could ask ourselves: why would collaborative governance structures be recommended in the management of the Covid-19 pandemic?

One possible answer is: in a pandemic, government decisions cannot be the only ones to be taken once they are driven to political parties' interests rather than for technical reasons. Such decisions we have seen occurring daily, in disputes among the federal, state and municipal public authorities, compromising the effectiveness of civil action in the crisis management, implying in the reduction of the devastating effects of the pandemic.

Another issue to highlight is that the contemporary world society lacks, more than ever, governance structures to manage complex issues such as a pandemic. We mean a social and democratic regulation of the world order, considering the number of actors in action, sometimes in a disconnected way, or focused on the interests of a few countries. Undoubtedly, times of crisis demand urgent and important global governance structures, such as the one caused by the Covid-19 pandemic. However, Arturi (2003) had already warned that the creation of a global and democratic public space would have crucial challenges, such as the relativization of the influence of state entities.

Therefore, the emergence is the urgent institutional arrangements for the global governance of major existential dangers (VEIGA, 2000), as exemplified by climate change and world pandemics. The main purpose is to contribute to the effectiveness of biosphere health, aka planetary health.

Eventually, at any geographic scale, collaborative governance requires practices qualified as democracy, and this is something the contemporary world misses.

\section{References Références Referencias}

1. Ansell, C.; Gash, A. (2007). Collaborative Governance in Theory and Practice. Journal of Public Administration Research and Theory, 18(4), 543-571.

2. Arturi, C. S. (2003).Os desafios para a instauração de uma governança mundial democrática na atual conjuntura internacional: síntese de um debate. Indic. Econ. FEE, 31(1), 75-94.

3. Bartz, C. R. F.; Turcato, J. C.; Baggio, D. K. (2019). Governança colaborativa: um estudo bibliométrico e conceitual da última década de publicações. Desenvolvimento Regional em debate, vol. 9, 800-817.

4. Bodin, O. (2017). Collaborative environmental governance: achieving collective action in social ecological systems. Science, 357(6352), 659-668.

5. Coase, R. (1937). The Nature of the Firm. Económica, 4, 386-405.

6. Dallabrida, V. R.(2003). Gobernanza y Planificación Territorial: para la institucionalización de una práctica de concertación público-privada. Documentos y Aportes en Administración Pública y Gestión Estatal, 4(3), p. 61-94.

7. Governança Territorial. In Siedenberg, D. R. (Org.), Dicionário do Desenvolvimento Regional (pp. 99100) Santa Cruz do Sul: EDUNISC.

8. Dallabrida, V. R. Governança Territorial. (2014). In Boullosa, R. F. (Org.), Dicionário para a formação em Gestão Social (v. 1, pp. 91-94). Salvador: CIAGS/UFBA.

9. Dallabrida, V. R.(2015a). Governança Territorial: do debate teórico à avaliação da sua prática. Análise Social, 50(2), 304-328.

10. Dallabrida, V. D. (2017). Governança Territorial. In Griebeler, M. P. D.; Riedl, M. (Org.), Dicionário de Desenvolvimento Regional e Temas Correlatos (1. ed., pp. 225-228). Porto Alegre: Editora Conceito.

11. Dallabrida, V. R. (2018). Governança Territorial: uma aproximação ao estado da arte e uma proposta metodológica para análise de sua prática. In: Baggio, A. F.; Kelm, M. L.; Baggio, D. K. (Org.), Governança Corporativa, Cooperativa e Territorial: Teorias, Experiências Nacionais e Internacionais (v. 1, pp. 117-171). Porto Alegre: SESCOPP.

12. Dallabrida, V. R. Práticas de governança territorial e seus desafios. (2015b). InSilva, I. C.; Frangella, S.; Aboim, S.; Viegas, S. M. (Org.), Ciências Sociais Cruzadas entre Portugal e o Brasil (pp.57-73). Lisboa: Imprensa Ciências Sociais.

13. Dallabrida, V. R. (no prelo). Território e Governança Territorial, Patrimônio e Desenvolvimento Territorial: estrutura, processo, forma e função na dinâmica territorial do desenvolvimento.

14. Decreto $n^{\circ}$ 10.277, de 16 de março de 2020. (2020a). Institui o Comitê de Crise para a Supervisão e monitoramento dos Impactos da Covida-19. Brasília, DF. Recuperado de http://www.planalto. gov.br/ccivil_03/_Ato2019-2022/2020/Decreto/ D102 77.htm

15. Decreto $n^{\circ}$ 10.289, de 24 de março de 2020. (2020b). Altera o Decreto $n^{\circ} 10.277$, de 16 de março de 2020, para instituir o Centro de 
Coordenação de Operações, no âmbito do Comitê de Crise para Supervisão e Monitoramento dos Impactos da Covid19. Brasília, DF. Recuperado de http://www.planalto.gov.br/ccivil_03/_Ato20192022/2020/Decreto/D10289.htm

16. Emerson, K.; Nabatchi, T.; Balogh, S. (2012). An integrative framework for collaborative governance. Journal of Public Administration Research and Theory, 22(1), 1-29.

17. Farinós, J. D. (2008). Gobernanza territorial para el desarrollo sostenible: estado de la cuestión y agenda. Boletín de la A. G. E., 46, 11-32.

18. Farinós, J. D. (2015). Desarrollo Territorial y Gobernanza: refinando significados desde el debate teórico pensando en la práctica. Un intento de aproximación fronética. Desenvo/vimento Regional em debate, 5(2), 4-24.

19. Ferrão, J. (2013). Governança, governo e ordenamento do território em contextos metropolitanos. In: Ferreira, A. et al. (Ed.), Metropolização do Espaço: Gestão Territorial e Relações Urbano Rurais (pp. 225-282). Rio de Janeiro: Consequência.

20. Jessop, B. (2006). ¿Narrando el futuro de la Economía Nacional y el Estado Nacional? Puntos a considerar acerca del replanteo de la regulación y la re-invención de la gobernancia. Doc. aportes adm. pública gest. Estatal, 7, 7-44. (Trans. María D. Bertuzzi).

21. Kooiman, J. (2004). Gobernar em Gobernanza. Revista Instituciones y Desarollo, 16, 171-194.

22. Mayntz, R. (1998). New Challenges to Governance Theory. Jean Monet Chair Papers, 50, 1-25.

23. Milani, A.; Solinís, G. (2002). Repensar a democracia na governança mundial: algumas pistas para o futuro. In Milani, A.; Arturi, C.; Solinís, G. (Org.), Democracia e Govenança Mundial: que regulações para o Século XXI?(pp. 266-291). Porto Alegre: Editora Universidade/UFRGS/UNESCO.

24. Romero, D.; Molina, A. (2011). Collaborative networked organisations and customer communities: value co-creation and co-innovation in the networking era. Production Planning \& Control, 22(5-6), 447-472.

25. Sørensen, E.; Torfing, J. (2011). Enhancing collaborative innovation in the public sector. Administration \& Society, 43(8), 842-868.

26. Taylor, B.; De Loë, R. C. \& Bjornlund, H. (2012). Evaluating knowledge production in collaborative water governance. Water Alternatives, 6(1), 42-66.

27. Torfing, J. (2007). Introduction: Democratic network governance. In Marcussen, M.; Torfing, J. (Ed.), Democratic network governance in Europe (pp. 1-22). London: Palgrave Macmillan.

28. Veiga, J. E. (2020). "Saúde Planetária": do que estamos falando? Pagina 22. Recuperado em: https://pagina22.com.br/2020/04/30/saudeplanetaria-do-que-estamos-falando. Acesso em 04-05-2020.

29. Williamson, O. E. (1996). The Mechanisms of Governance. New York: Oxford University Press. 